\title{
Maximum Level of COVID-19 Vaccination in Rich and Democratic Countries, and in Other Political Systems
}

Mario Coccia ( $\nabla$ mario.coccia@cnr.it)

National Research Council of Italy

\section{Research Article}

Keywords: COVID-19 vaccination, Vaccination decision, Vaccine hesitancy, Vaccine resistance, Economic development, Democracy, Public health, Green pass regime, Immunity passports, Vaccine passports, Public health ethics

Posted Date: December 2nd, 2021

DOI: https://doi.org/10.21203/rs.3.rs-1131026/v1

License: (a) This work is licensed under a Creative Commons Attribution 4.0 International License. Read Full License 


\title{
MAXIMUM LEVEL OF COVID-19 VACCINATION IN RICH AND DEMOCRATIC COUNTRIES, AND IN OTHER POLITICAL SYSTEMS
}

\author{
MARIO COCCIA \\ CNR -- NATIONAL RESEARCH COUNCIL OF ITALY \\ Collegio Carlo Alberto, Via Real Collegio, n. 30 \\ 10024 - Moncalieri (TO), Italy
}

Contact E-mail: mario.coccia@cnr.it

\begin{abstract}
Coronavirus Disease 2019 (COVID-19) vaccinations play a main role in the immunization program of countries to decrease the numbers of COVID-19 related infected individuals and deaths. However, countries, after a certain share of people vaccinated against COVID-19 have to cope with vaccine hesitancy and resistance in population. One of the fundamental problems is the detection of the max share of people vaccinable between countries without the introduction of any rule that affects basic aspects of individual freedoms of people in public and private life. The study here confronts this problem with a global analysis based on $N=150$ countries, using relationships between socioeconomic, institutional and political variables, and levels of vaccination. Results reveal that the share of people vaccinated increases with the level of development (and democratization) of countries, achieving the maximum level of about $70 \%$; beyond this level, the share of vaccination starts to decrease across countries. Moreover, findings reveal that governments with Monarchy and Parliamentary Monarchy have average share of people vaccinated higher than Mixed Executives. These main findings suggest that in developed and democratic countries the maximum level of vaccination has a physiological limit, but many Western (democratic) countries are applying restriction rules (e.g., green pass/vaccine passport) to overcome this max level reducing and regulating, at the same time, many aspects of public and private life of individuals. Discussion explains these sociopolitical phenomena with aspects of politics of fear, focused on deaths of COVID-19, and of strong leaders having domestic and international support that apply rules in contexts of social insecurity with consequential reduction of equity, trust and solidarity and increase of socioeconomic issues. All these results here could aid policymakers to prepare sustainable policy responses against COVID-19 in society without distressing basics of democracy with rules of autocratic systems that can generate economic and social deterioration, and problems for mental health and economic conditions of people in society.
\end{abstract}

Keywords: COVID-19 vaccination; Vaccination decision; Vaccine hesitancy; Vaccine resistance; Economic development; Democracy; Public health; Green pass regime; Immunity passports; Vaccine passports; Public health ethics.

\section{Declaration of competing interest}

The author declares that he is the sole author of this manuscript, and he has no known competing financial interests or personal relationships that could have appeared to influence the work reported in this paper.

This study has no funders. 


\section{GOALS OF THE INVESTIGATION}

Coronavirus disease 2019 (COVID-19) is an infectious illness caused by the novel Severe Acute Respiratory Syndrome Coronavirus 2 (SARS-CoV-2), which appeared in late 2019 (Bontempi et al., 2021; Bontempi and Coccia, 2021; Coccia, 2020, 2020a, 2020b, 2021)1. COVID-19 is still circulating in 2021 with mutations of the novel coronavirus that generate continuous COVID-19 infections and deaths in manifold countries (Johns Hopkins Center for System Science and Engineering, 2021; Vinceti et al., 2021). High numbers of COVID-19 related infected individuals and deaths worldwide have supported the development of different types of vaccines based on viral vector, protein subunit and nucleic acid-RNA (Abbasi, 2020; MAYO CLINIC 2021). The investigation of vaccination plans between countries is a crucial aspect to determine how the novel infectious disease can be controlled and/or eradicated in the population (Aldila et al., 2021; Prieto Cruriel, et al. 2021). Vaccination has the potential effect to reduce the diffusion of COVID-19, to relax non-pharmaceutical measures and maintain low basic reproduction number, but an important point is to clarify the optimal levels of administering of vaccines between countries to reduce negative effects in society (Coccia, 2021a). Akamatsu et al. (2021) argue the vital role of governments to implement an efficient campaign of vaccination to substantially reduce infections in society, and avoid the collapse of healthcare system (cf., Coccia, 2021a, 2021b, 2022). Aldila et al. (2021) maintain that higher levels of vaccination rate can eradicate COVID-19 in population by approaching herd immunity to protect vulnerable individuals (cf., Anderson et al., 2020; de Vlas and Coffeng, 2021; Randolph and Barreiro, 2020). Herd immunity indicates that only a share of population needs to be immune and therefore no longer susceptible to a viral agent (by overcoming natural infection or through vaccination) for controlling large outbreaks (Fontanet and Cauchemez, 2020). Scholars estimate the proportion of a population that needs to be vaccinated to support herd immunity, ceteris paribus (Redwan, 2021). The threshold level depends on basic reproduction number, $\mathrm{R}_{0}$ - the number of cases, on average, spawned by one infected individual in an otherwise fully susceptible (Coccia, 2020; Kwok et al., 2020). The

${ }^{1}$ Cf. also Coccia, 2020c, 2021d, 2021e, 2021f, 2021g, 2021h. 
index $\mathrm{R}_{0}$ assumes that everyone is susceptible to virus, but the level changes as the epidemic evolves, since it depends on changes in susceptibility of the population, mitigation and restriction policies, circulation of variants, season, etc. (Aschwanden, 2020, 2021; Coccia, 2021a; Dashtbali and Mirzaie, 2021). Kwok et al. (2021) argue that the minimum proportion (\%) of total population required to confer COVID-19 immunity change, such as it can be 5.66 in Kuwait and 85 in Bahrain. In this context, a fundamental problem in COVID-19 pandemic crisis is the detection of maximum level of vaccinated people between countries without compulsory actions on citizens and if the maximum level of vaccinated people changes according to the types of executives (e.g., mixed executives, monarchy, etc.). The natural acceptance of COVID-19 vaccines between countries can be a main proxy to assess the maximum level of consent in rich and democratic settings, whereas actions of nations for overcoming the max level of vaccinated people with autocratic interventions that reduce individual freedoms can show consequential socioeconomic issues.

This study in the presence of COVID-19 pandemic crisis can clarify some relations to design best practices of crisis management for vaccination plans directed to increase vaccinated people using rewards systems in democratic settings having little amount of oversight on public and private life rather than compulsory rules that reduces individual freedoms (cf., Coccia, 2019g). This study is part of a large research project to explain drivers of transmission dynamics of COVID-19 and design effective policy responses to cope with and/or to prevent pandemic threats in society (Coccia, 2020, 2020a, 2020b, 2020c, 2021, 2021a, 2021b, 2021c, 2021d, 2021e, 2021f, 2021g, 2021h).

\section{METERIALS AND METHODS}

\subsection{Source and sample}

The sample of this study is $N=150$ countries worldwide.

\subsection{Measures for statistical analyses}

- Vaccination is measured by percent share of people fully vaccinated against COVID-19 over SeptemberOctober 2021. Data refer mainly to October 2021 but some countries, because of difficulty in the gather and transmission of information, provide data of September 2021, such as Algeria, Afghanistan, Turkmenistan, 
Madagascar, etc. The data here considers all types of COVID-19 vaccines used in different countries, i.e., vaccines by Johnson \& Johnson, Oxford/AstraZeneca, Pfizer/BioNTech, Sinopharm/Beijing, Sinovac, Sputnik V and Moderna (Ritchie et al., 2020). Of course, every country has been using a different combination of these COVID-19 vaccines to protect the population. Source: Our World in Data (2021).

- Gross Domestic Product (GDP) per capita in 2020. GDP per capita (constant 2010 US\$). GDP per capita is gross domestic product divided by midyear population. GDP is the sum of gross value added by all resident producers in the economy plus any product taxes and minus any subsidies not included in the value of products. It is calculated without making deductions for depreciation of fabricated assets or for depletion and degradation of natural resources. Data are in constant 2010 U.S. dollars. Source: The World Bank (2021).

- Democracy is measured using score of Freedom House Methodology. A country or territory is assessed considering indicators of political rights and civil liberties. The average of a country or territory's political rights and civil liberties ratings is called the Freedom Rating, and the level determines the Freedom status given by:

- Free countries (1.0 to 2.5 Combined Average of the Political Rights and Civil Liberties)

- $\quad$ Partly Free (3.0 to 5.0)

- $\quad$ Not Free (5.5 to 7.0$)$

Source: Freedom House (2021, 2021a).

\subsection{Model and data analysis procedure}

- $\quad$ Level of economic development of countries is categorized using GDP per capita (constant 2010 US\$) in 2020 as follows (The World Bank, 2021):

- HIGH economic development $>\$ 15,000$

- MEDIUM economic development (\$2,000-14,999)

- LOW economic development $<\$ 2,000$ 
- $\quad$ Countries are also categorized using the typology of executives as follows (Norris, 2008):

- DIRECT Democracy

- PARLIAMENTARY Monarchy

- PRESIDENTIAL Republic

- MIXED Executives

- MONARCHY

- MILITARY State

Data are analyzed with descriptive statistics given by arithmetic mean and standard error of the mean, using the categorization of economic development, freedom status and type of executives between countries.

The normality of distributions of variables under study is checked with skewness and kurtosis coefficients and considering that some variables are not appropriate for parametric analyses, they are transformed in logarithmic scale for performing regression analysis.

After that, the analysis of simple regression applies quadratic models because they fit the scatter of data and detect nonlinear effects of relations understudy. The specification of $\log$ - $\log$ quadratic model is given by:

$\log y_{i, t}=\alpha_{0}+\beta_{1} \log \mathrm{x}_{\mathrm{i}, \mathrm{t}-1}+\beta_{2} \log \mathrm{x}_{\mathrm{i}, \mathrm{t}-1}^{2}+u_{i, t}$

where:

O $x_{i, t-1}=$ GDP per capita (constant 2010 US $\$$ ) in 2020

○ $y_{i, t}=$ Share $\%$ of people fully vaccinated against COVID-19 over September-October 2021

○ $u_{i, t}=$ Error term

country $i=1, \ldots, n ; \quad$ t=time

Remark 1: The square of GDP per capita in model [1] is introduced to consider the possibility of non-linear effects in the relation under study.

Remark 2: Model [1] has a time lag effect between explanatory ( $\mathrm{t}-1$ ) and dependent variable (t) to reduce the endogeneity of explanatory variable in model and provide reliable (estimated) parameters. 
Finally, the optimization of the estimated relationships [1] is performed with the perspective of maximization of the equation [1] to find the maximum levels of share \% of people fully vaccinated against COVID-19 in society. In particular, the estimated relationships [1] are objective functions of one (real) variable given by polynomial functions of second order. These estimated relations [1] are continuous and infinitely differentiable functions. The calculus applied on functional relation [1] provides the optimal levels of share $\%$ of people fully vaccinated against COVID19 in countries. Model [1] is applied using the Freedom status per countries (Free, Partly Free or Not Free) and total number of countries $(N=150)$.

Results are described in tables and presented in figures with the estimated relationships and optimal (max) level of share $\%$ of people fully vaccinated against COVID-19 in society.

Statistical analyses are performed with the Statistics Software SPSS® version 26.

\section{RESULTS}

Table 1. Descriptive statistics of fully vaccinated people per level of GDP per capita and democracy, $N=150$ countries

\begin{tabular}{llccc}
\hline $\begin{array}{l}\text { Level of economic development } \\
\text { using GDP per capita in 2020 }\end{array}$ & Freedom Status & \multicolumn{2}{c}{$\begin{array}{c}\text { Fully vaccinated } \\
\text { September - October 2021 }\end{array}$} \\
\hline \multirow{2}{*}{ HIGH $>\$ 15,000$} & - FREE & $\mathrm{N}$ & Mean $(\%)$ & Std. Error \\
\cline { 2 - 4 } & - PARTLY FREE & 36 & 63.99 & 10.39 \\
& - NOT FREE & 3 & 66.63 & 11.99 \\
MEDIUM $(\$ 2,000-14,999)$ & - FREE & & 59.65 & 18.14 \\
& - PARTLY FREE & 24 & 38.31 & 20.28 \\
& - NOT FREE & 24 & 28.71 & 18.36 \\
LOW $<\$ 2,000$ & - FREE & 17 & 23.22 & 19.19 \\
& - PARTLY FREE & & & 8.32 \\
& - NOT FREE & 22 & 7.42 & 5.41 \\
\hline
\end{tabular}

Research paper 2021 Coccia M. 2021. Maximum level of COVID-19 vaccination in rich and democratic countries, National Research Council of Italy 
Table 1 shows that partially free and rich countries have a higher share of people fully vaccinated against COVID19, whereas free countries having a medium level of GDP per capita have a higher share of vaccinated people than partially free and not free countries.

Table 2. Descriptive statistics of fully vaccinated per type of executives, $N=150$ countries

\begin{tabular}{lccc}
\hline \multicolumn{1}{c}{ Type of Executives } & \multicolumn{2}{c}{$\begin{array}{c}\text { Fully vaccinated } \\
\text { September - October 2021 }\end{array}$} \\
\hline & $\mathrm{N}$ & Mean $(\%)$ & Std. Error \\
\cline { 2 - 4 } DIRECT Democracy & 2 & 63.05 & 2.25 \\
PARLIAMENTARY Monarchy & 21 & 52.01 & 5.34 \\
PRESIDENTIAL Republic & 39 & 27.21 & 3.78 \\
MIXED Executives & 78 & 31.32 & 3.06 \\
MONARCHY & 7 & 46.54 & 5.99 \\
MILITARY State & 3 & 8.97 & 3.37 \\
\hline
\end{tabular}

Table 2 shows that countries with monarchy and parliamentary monarchy have a higher share of people fully vaccinated against COVID-19 than countries having mixed executives and presidential republic.

Table 3. Regression analyses of people fully vaccinated in 2021 on GDP per capita 2020 in free, partly free and not free countries (log-log quadratic model [1])

\begin{tabular}{|c|c|c|c|c|}
\hline & \multicolumn{3}{|c|}{ FREEDOM STATUS IN COUNTRIES (LEVEL OF DEMOCRACY) } & \multirow[b]{2}{*}{ TOTAL COUNTRIES } \\
\hline & FREE & PARTLY FREE & NOT FREE & \\
\hline Constant $\alpha$ & $-19.97 * * *$ & $-22.18^{* * *}$ & -2.484 & $-18.66^{* * *}$ \\
\hline (St. Err) & $(3.22)$ & $(6.04)$ & $(12.70)$ & $(2.65)$ \\
\hline Coefficient $\beta_{1}$ & $4.50 * * *$ & $5.049 * *$ & 0.456 & $4.194 * * *$ \\
\hline (St. Err.) & $(.70)$ & $(1.534)$ & $(3.03)$ & $(.62)$ \\
\hline Coefficient $\beta_{2}$ & $-.209 * * *$ & $-.243 *$ & -.019 & $-.192^{* * *}$ \\
\hline (St. Err.) & $(.037)$ & $(.096)$ & $(.179)$ & $(.035)$ \\
\hline $\mathrm{R}^{2}$ & .73 & .65 & .32 & .67 \\
\hline rr. of Estimate) & $(.49)$ & $(1.07)$ & $(1.24)$ & $(.904)$ \\
\hline$F$ & $85.25^{* * *}$ & $42.17 * * *$ & $6.99 * *$ & $144.95^{* * *}$ \\
\hline
\end{tabular}

Note: Dependent (response) variable is: Share (\%) of people fully vaccinated against COVID-19 in 2021 over September-October 2021 period. Explanatory variable is: Gross Domestic Product per capita in 2020

Significance: ${ }^{* * *} p$-value $<0.001 ;{ }^{* *} p$-value $<0.01{ }^{*} p$-value $<0.05$ 


\section{FREE Countries}

The estimated relationship of FREE countries, based on results of table 3, is:

$$
j_{i, t}=-19.97+4.50 w_{\mathrm{i}, \mathrm{t}-1}-0.209 w_{\mathrm{i}, \mathrm{t}-1}^{2}
$$

The function is given by

$$
j=-19.97+4.50 w-0.209 w^{2} \quad[2]
$$

the necessary condition to maximize the function $j$ is:

$\frac{d j}{d w}=j^{\prime}(w)=4.50-0.418 w=0$

The first derivative equal to 0 is:

$$
j^{\prime}(w)=0 \Rightarrow \quad w^{*}=\frac{4.50}{0.418}=10.76 \text { level of GDP per capita }(\text { in log })=\$ 47,098
$$

Now if we replace $w^{*}$ in equation [2], we have $j=4.2525$ (in $\log$ scale) which is transformed by $e^{\mathrm{j}}=70.28 \%=$ the max share of people fully vaccinable in free countries. The increase of this share beyond the maximum achievable level in free countries in general it needs the application of suitable rewards or policies of restriction associated with a high degree of control and regulation over public and private life of individuals that can generate social and economic issues, reducing the democratic environment and individual freedoms (Figure 1).

Research paper 2021

Coccia M. 2021. Maximum level of COVID-19 vaccination in rich and democratic countries, National Research Council of Italy 


\section{Log Share of people fully vaccinated in September - October 2021 FREE Countries}

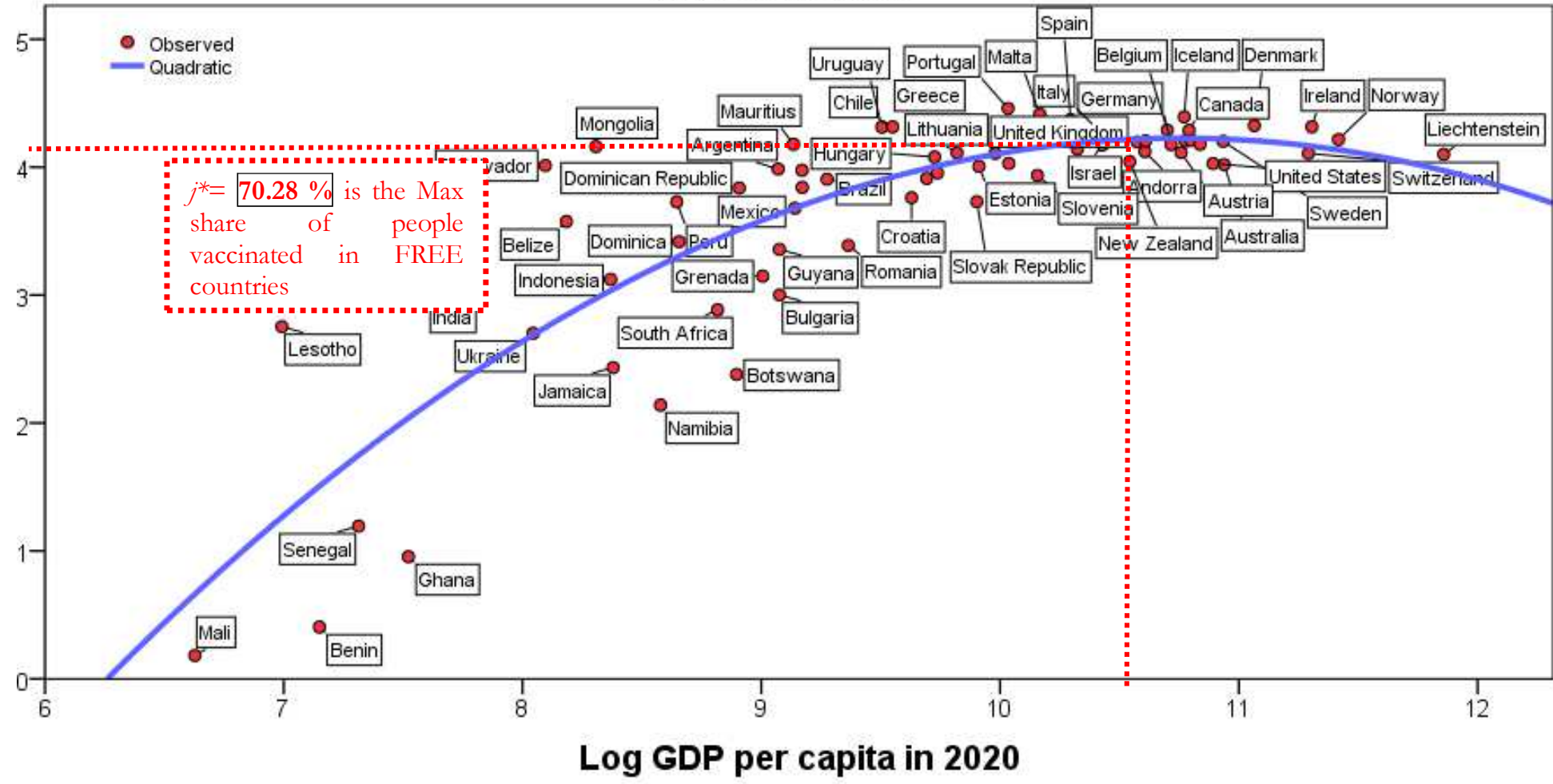

Figure 1. Relation of share of people vaccinated against COVID-19 (\%) on GDP per capita in free countries based on quadratic model [1], with the maximum level of vaccinated people.

\section{PARTLY FREE Countries}

The estimated relationship of FREE countries, based on results of table 3, is:

$$
k_{i, t}=-22.18+5.049 b_{\mathrm{i}, \mathrm{t}-1}-0.243 \mathrm{~b}_{\mathrm{i}, \mathrm{t}-1}^{2}
$$

The function is given by

$$
k=-22.18+5.049 b-0.243 b^{2}
$$

the necessary condition to maximize the function $k$ is:

$\frac{d k}{d b}=k^{\prime}(b)=5.049-0.486 b=0$

The first derivative equal to 0 is:

Research paper 2021 Coccia M. 2021. Maximum level of COVID-19 vaccination in rich and democratic countries, National Research Council of Italy 


$$
k^{\prime}(b)=0 \Rightarrow \quad b^{*}=\frac{5.049}{0.486}=10.389 \text { level of GDP per capita }(\text { in } \log \quad)=\$ 32,500.15
$$

Now if we replace $\mathrm{b}^{*}=10.389$ in equation [3], we have $k=4.04675$ (in $\log$ scale) which is transformed by $e^{\mathrm{k}}=$ $57.21 \%=$ the max share of people fully vaccinated in partially free countries. The increase of this share beyond the maximum achievable level in partly free countries in general it needs the application of appropriate rewards or additional interventions of control and regulation over public and private life that generate social and economic issues, reducing the democratic environment and individual freedoms further (Figure 1).

\section{Log Share of people fully vaccinated in September-October 2021}

PARTLY FREE Countries

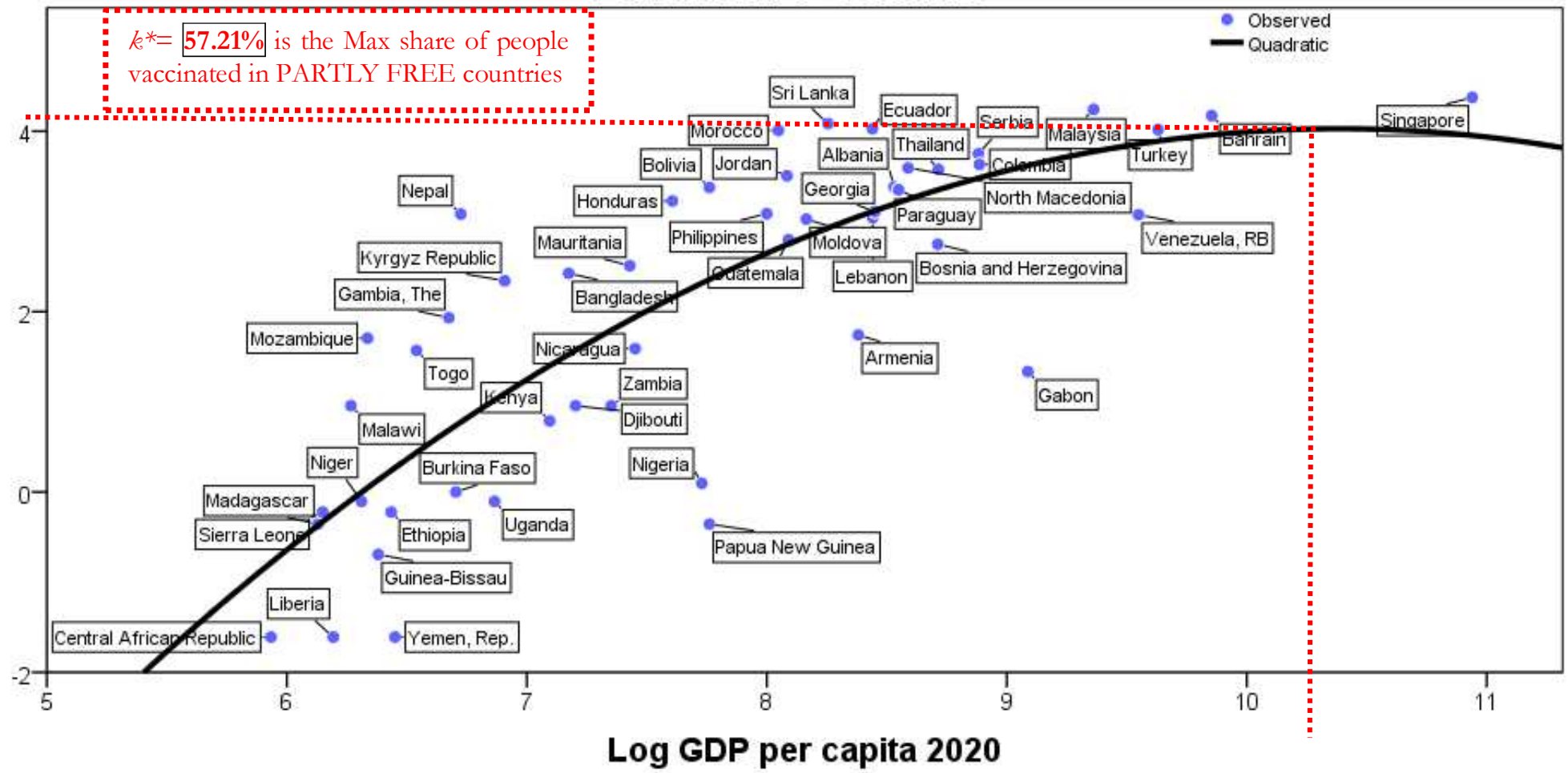

Figure 2. Relation of share of people vaccinated against COVID-19 (\%) on GDP per capita in partly free countries based on quadratic model [1], with the maximum level of vaccinated people.

Research paper 2021 Coccia M. 2021. Maximum level of COVID-19 vaccination in rich and democratic countries, National Research Council of Italy 
The estimated relationship in NOT FREE countries has not significant parameters as indicated in table 3 and we do not proceed with the approach of optimization because the results are misleading

\section{TOTAL Countries}

The estimated relationship of total number of countries, based on results of table 3 , is:

$$
q_{i, t}=-18.66+4.194 g_{\mathrm{i}, \mathrm{t}-1}-0.192 \mathrm{~g}_{\mathrm{i}, \mathrm{t}-1}^{2}
$$

The function is given by

$$
q=-18.66+4.194 g-0.192 g^{2}
$$

the necessary condition to maximize the function $q$ is:

$\frac{d q}{d g}=q^{\prime}(g)=4.194-0.384 g=0$

The first derivative equal to 0 is:

$$
q^{\prime}(g)=0 \Rightarrow \quad g^{*}=\frac{4.194}{0.384}=10.922 \text { level of GDP per capita }(\text { in } \log )=\$ 55,374.53
$$

Now if we replace $g^{*}$ in equation [4], we have: $q=4.2432$ (in $\log$ scale) which is transformed by $e^{\mathrm{q}}=69.63 \%$ $=$ the max share of people fully vaccinated between all countries. The remaining share is associated with a natural hesitancy of people and individual freedoms typical of rich and democratic countries. In addition, as explained before, the increase of this share beyond the maximum level in countries, in general it needs the application of suitable rewards or restriction policies directed to a high degree of control and regulation over public and private life that generate social and economic issues, reducing the democratic environment and individual liberties of people (Figure 3). 


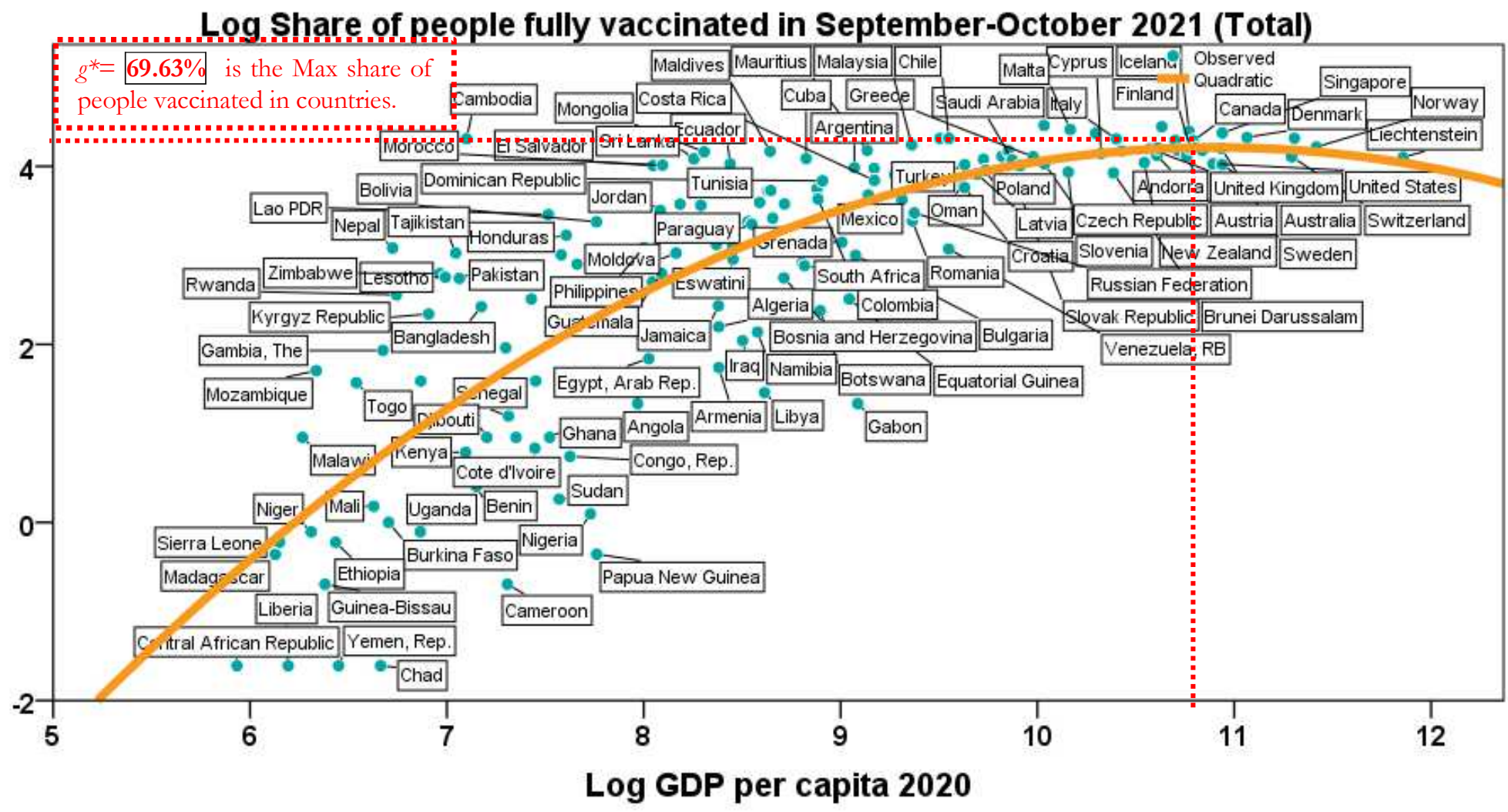

Figure 3. Relation of share of people vaccinated against COVID-19 (\%) on GDP per capita in all countries $(N=150)$ based on quadratic model [1], with the maximum level of vaccinated people.

In general, the share of vaccinated against COVID-19 increases with the wealth of nations but it has a physiological maximum level of about $70 \%$ between countries at global level (in partly free countries is lower).

Research paper 2021 Coccia M. 2021. Maximum level of COVID-19 vaccination in rich and democratic countries, National Research Council of Italy 
DISCUSSIONS ON THE GROWTH OF VACCINATED PEOPLE USING REGULATORY RULES IN

\section{DEMOCRATIC SETTINGS}

Anttiroiko (2021) analyzes how socioeconomic context, institutional arrangements, culture, and technology level can affect policy responses to the pandemic crisis in Eastern and Western countries ${ }^{2}$. Studies show that in average policy responses in Europe over 2020 tended to be less stringent than countries in East Asia (Ritchie et al., 2020). Moreover, Anttiroiko (2021) highlights that Asian countries have applied with determination policy responses to cope with COVID-19 crisis because of the early diffusion of pandemic in their regions that has supported learning processes. Instead, European countries have different culture, institutions, political systems and approaches to cope with crises and have also to face with privacy and human rights issues, protests against governments for lockdown, restriction measures, vaccine passports, etc. (Coccia, 2005a, 2017, 2017b; 2018a, 2019c, 2019d, 2021i; Coccia and Bellitto, 2018; Coccia and Benati, 2018)Findings here reveal that the share of vaccinated people against COVID-19 increases with the wealth of nations, but it has a physiological limit of about $70 \%$ between countries. One of the main issues is the vaccine hesitancy in a portion of population associated with individual freedoms of rich and democratic countries (cf., Verger and Peretti-Watel, 2021). Murphy et al. (2021) found that general adult populations of Ireland and the United Kingdom had vaccine hesitancy/resistance for 35\% and 31\% respectively. Schwarzinger et al. (2021) analyze the determinants of COVID-19 vaccine acceptance or refusal and suggest that highlighting the benefits in terms of herd immunity can reduce hesitation about COVID-19 vaccines (cf., Buttenheim and Asch, 2013; Echoru et al., 2021; Kanyike et al., 2021). In fact, COVID-19 vaccination is associated with levels of public trust in governments that have to be built and reinforced in the presence of situation of crisis management (cf., Soveri et al., 2021; Vergara et al., 2021). Abuza (2020) argues that the effectiveness of policies in the presence of biological threats is based on

\footnotetext{
${ }^{2}$ For role of science and technology for economic and social change see: Ardito et al., 2021; Calabrese et al., 2005; Coccia, 2005; Coccia, 2008, 2014, 105, 2016, 2017a, 2017c, 2017d, 2018b, 2018c, 2019, 2019a, 2019b, 2019f; Coccia, 2020d, 2020e, 2020f, 2020g; Coccia and Cadario, 2014; Coccia and Finardi, 2012, 2013; Coccia and Rolfo, 2000, 2008; Coccia and Watts, 2020; Pagliaro and Coccia, 2021. 
leadership and competence, rather than political regimes of countries. Some countries in Western world are stressing democratic society with restrictions to individual freedoms to increase the maximum share of people fully vaccinated (estimated here) by introducing green pass (or vaccine certificate or immunity certificate that here are used interchangeably), as a rule for entering certain businesses and public spheres and/or use public transport or to go to work (as in Italy); this bureaucratic tool is creating a hot debate and manifold socioeconomic issues (Brown et al., 2021; Chantler et al., 2019; Coccia, 2018d; Dye and Mills, 2021; Phelan, 2020). Brown et al. (2021) suggest that the implementation of immunity passports ought to be applied to maximize their benefit without reducing wellbeing of people. Saban et al. (2021) maintain that policymakers should use a measured approach to protect public health, with minimum infringement on citizens' rights. Kamin-Friedman and Peled Raz (2021) argue that green pass: “imposes restrictions on the movement of individuals who had not been vaccinated or who had not recovered, it is not consonant with solidarity and trust building. Implementing the Green Pass provision while advancing its effectiveness on the one hand, and safeguarding equality, proportionality, and fairness on the other hand may imbue this measure with ethical legitimacy despite involving a potential breach of trust and solidarity”. Luster et al. (2021) maintain that: "the Green Pass policy raises practical, legal and ethical concerns. ... any privileges or restrictions guided by one's COVID-19 immunization status must be designed with the utmost attention to prevent a disproportionate violation of the human rights of the non-vaccinated and the public at large. ... Green Pass policies might entrench existing discriminatory structures, ensuring equality is vital in moving forward. ... Despite the removal of the Green Pass in Israel, discussions continue regarding its modified reimplementation”. Overall then, Green Pass or vaccine passport was originated to be an incentive to support vaccination plans, but some countries in Europe are using this bureaucratic tool to penalize people without vaccination, reducing individual freedoms, increasing the discrimination between people in social, cultural and sporting activities, fostering tensions between different social groups, and as a consequence reducing equity, trust and solidarity between people with consequential socioeconomic issues (Kosciejew et al., 2021; Waitzberg et al., 2021; Wilf-Miron et al., 2021). In the presence of persistent green pass regime, protests and socioeconomic issues are opened up, which will support authoritarian rules to reduce 2021 Coccia M. 2021. Maximum level of COVID-19 vaccination in rich and democratic countries, National Research Council of Italy 
individual freedoms leveraging potential health risks (cf., Wong, 1991). The side effects of this policy of restrictions in countries can be explained with two main aspects that are discussed in following sections.

\section{$\square \quad$ Politics of fear}

Hobbes (1996) maintains that having control over human fears meant holding power in the society. In general, the interaction between fear and politics is a main field of interest in science (Debiec and LeDoux, 2004; Robin, 2004). Gore (2004) argues that the politics of fear is directed to distort the political reality of a nation by creating fear in population that is disproportionate to actual dangers. In fact, in contexts of uncertainty, governments tend to create administration's policies with inconsistencies, ambiguities and little transparency to reduce accountability to the people and the public interest. Gore (2004) also argues that in specific circumstances: " there has been a disturbing willingness_-even eagerness_-to misrepresent the true nature of the policy involved and its real implications". In addition, Gore (2004) points out that the U.S. administration has used the politics of fear in economic policy for

fiscal reforms; in many European countries, governments use the politics of fear based on COVID-19 pandemic to apply health policies that reduce individual freedoms and regulate the public and private life of people (cf., WilfMiron et al., 2021). Gore (2004, square bracket added) also argued that: "[U.S.] administration uses fear of the problems of old age to contrive an illusory drug bill that essentially transfers billions from the people to the pockets of the large pharmaceutical companies". Governments can use fear for purposes that are not disclosed, then fear itself can quickly become a self-perpetuating and free-wheeling force that weakens national character, diverting attention from real threats and other problems, sowing confusion (Lupia and Menning, 2009). Hence, the intentional use of fear to manipulate the political process can create many vulnerabilities in population, nation and society. 


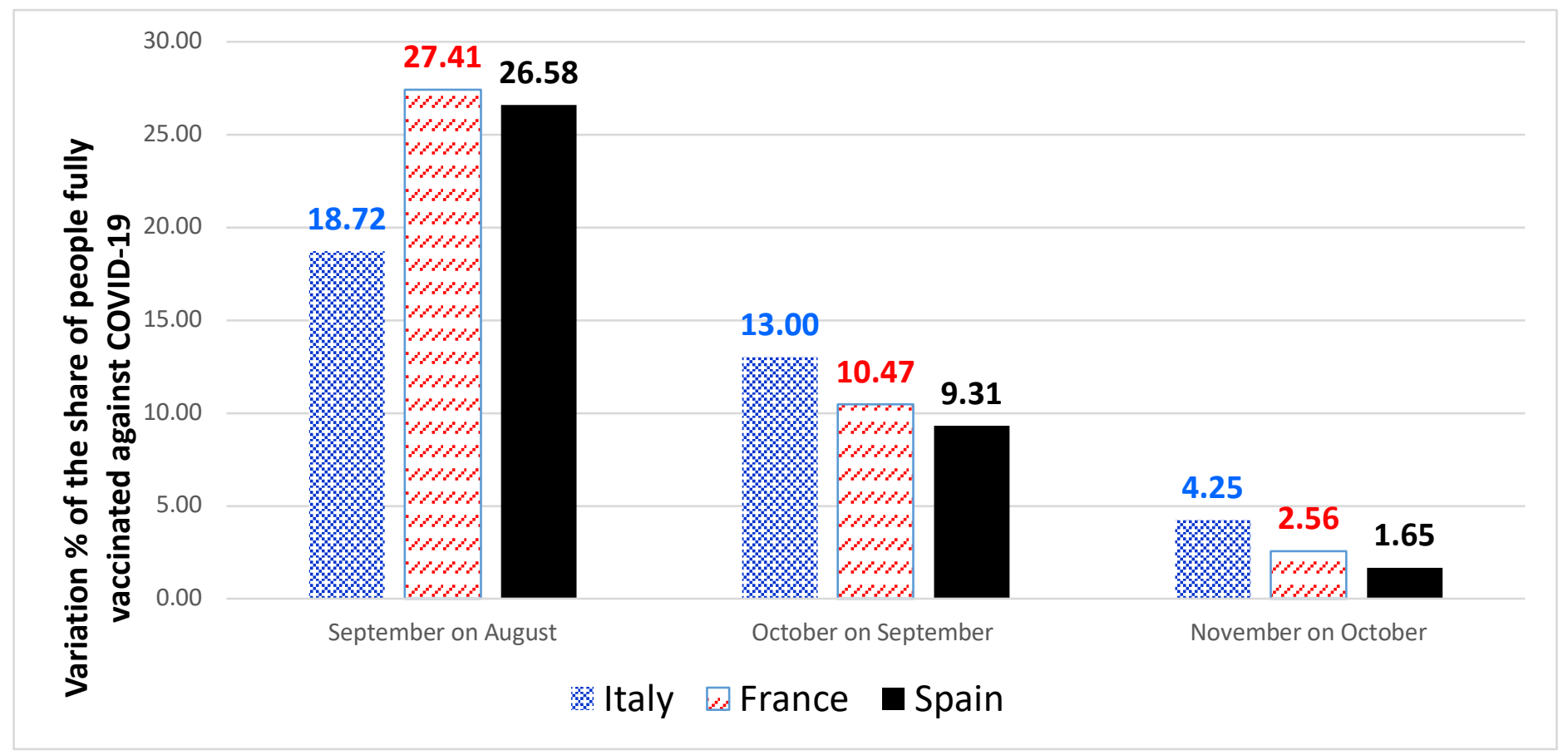

Figure 4. Percent variation (monthly) of the share of people fully vaccinated against COVID-19 in Italy and France (having Green Pass/vaccine passport regime) vs. Spain without green pass certificate from July to November 2021. Note: France introduced Green Pass on 21 July 2021; Italy on 6 August for museums, cultural places and events; ${ }^{\text {st }}$ September for transportation of long distance; 15 October for all working places and $6^{\text {th }}$ December 2021 also for urban transportation (subway, buses, etc.).

Prewitt (2004) think that institutional fear is a fundamental aspect of liberal thought and constitutional democracy. Arato (2004) argues that Hobbes formulated "a fear of the state of nature, of the war against all, is what drives us to establish something like the modern state". Finally, Arato (2004) shows the important role of "institutional fear" that underpins the social contract in liberal theory. In particular, Arato (2004), focusing on case study of the U.S.A., maintains that liberalism can produce a weak state having a poor regulation of emergency powers, such that the "emergency regime" tends to be constructed largely outside the Constitution generating problematic aspects in society (Prewitt et al., 2004; Robin, 2004). A practical example is the COIVID-19 pandemic crisis, and European countries to increase the max share of people vaccinated (as estimated here, beyond $70 \%$ of population) tend to apply politics of fear associated with informal authoritarian rules that stress constitutional principles (e.g., immunity passport), reduce the individual freedoms and create socioeconomic problems, with low benefits to cope with 
COVID-19 pandemic. In fact, figure 4 shows that the effects of Green pass regime, based on authoritarian rules, generate a moderate growth of vaccinations that disappears in the short-run, but it generates social issues for the reduction of individual freedoms, the increase of discrimination of people in social, cultural and sporting activities, the growth of tensions between different groups, reduction of equity, trust and solidarity too (Kosciejew et al., 2021; Waitzberg et al., 2021; Wilf-Miron et al., 2021).

\section{$\square \quad$ Strong leaders and authoritarian rules in democracies}

The increase of vaccination in rich and democratic regions, by introducing restrictions and policies based on vaccine passport, is also associated with strong leaders having domestic and international support that can generate a substantial decline of democratic setting (Lavriča and Bieberb, 2021). This tendency of power in strong leaders, in the presence of crisis, is supported by a combination of social insecurity, cultural backlash and economic issues generated by pandemic crisis. To put it differently, the application of authoritarian rules in democratic systems is due to the emergence for strong leaders but also to social and economic insecurity that support authoritarian approaches that are exercised informally (Lavriča and Bieberb, 2021; cf., Coccia, 2019e). In fact, all political leaders guide restrictive interventions in a general framework in which they are considered "pragmatic reformers" and receive initially domestic and international support (Crowther 2017; Günay and Dzihic 2016; Vladisavljević 2019). Thus, the increasing public support to a strong political leader may be one of the causes of the rise in authoritarian rules in the Western countries in the presence of pandemic crisis, leveraging socioeconomic uncertainty and fear in society. These tendencies are generated in an institutional environment and countries having weaknesses of democratic institutions and balance of powers in the presence of emergencies and crisis.

\section{CONCLUSIONS AND PROSPECTS}

Findings here reveal that the share of vaccinated against COVID-19 increase with the wealth of nations, but it has a physiological maximum level of about $70 \%$ between (rich and democratic) countries. In addition, monarchy and parliamentary monarchy have a higher share of people fully vaccinated against COVID-19 than mixed executives 
and presidential republic. Some countries in Western world are straining democratic society with restrictions to individual freedoms to increase the maximum share of people fully vaccinated (estimated here) by introducing restriction policies, vaccine certificate and penalties as a rule that create socioeconomic issues, such as discrimination of people in social activities, tensions between different groups, reduction of equity, trust, etc. (Brown et al., 2021; Chantler et al., 2019; Coccia, 2018a, 2021c; Dye and Mills, 2021; Kosciejew et al., 2021; Waitzberg et al., 2021; WilfMiron et al., 2021). In particular, results here can explain some abuses in democratic countries based on a combination of the politics of fear and informally authoritarian rules ${ }^{3}$ applied by a strong leader under circumstances of social insecurity.

Although this study has provided interesting results, that are of course tentative, it has several limitations. First, a limitation of the study is the lack of data about total vaccinations in manifold countries. Second, not all the possible confounding factors that affect the diffusion of vaccination are taken into consideration and in future these factors deserve to be controlled for supporting results here. Third, the lack of integration of data with cultural aspects may have influenced the results of vaccination across countries making comparative analyses a problematic approach (Angelopoulos et al., 2020; Coccia, 2018). Fourth, country-specific health and social norms may affect the vaccination and mitigation policies. Finally, the estimated relationships in this study focus on variables in specific months (based on recent data available) but an extension of the period under study is needed in future development of the research here. Thus, the generalization of this results should be done with caution. Future research should consider new data, when available, and when possible, to examine also other variables between countries to explain dynamic relationships under study over time and space and their interaction with vaccination, vaccine certificate, restriction policy and other social norms between countries. Despite these limitations, the results presented here suggests the maximum sustainable level of people vaccinated between rich and democratic countries (that is roughly $70 \%$ ) and

\footnotetext{
${ }^{3}$ Wesołowski (1990) argues some axioms of the authoritarian regime, such as the state's power (state) is the fundamental mechanism of social integration and regulation; the state is an organism which stands above all other forms of social organization and exerts control over them; it uses violence when needed, etc.
} 
social and economic issues associated with the introductions of policy of restrictions and bureaucratic tools (e.g., immunity passport) to go beyond this limit using politics of fear and strong leaders. Hence, there is need for much more detailed research in these topics and this study encourages further investigations using lessons learned of COVID-19 pandemic crisis, also considering the interaction between effects of restrictions in societies and campaign of vaccination. Overall, then, many Western (democratic) countries are straining society with restrictions to individual freedoms to increase the maximum share of people fully vaccinated (with marginal results) by introducing vaccine passport and autocratic rules that impose restrictions to the movement of individuals who are not vaccinated, reducing equality and fairness between people. These aspects are applied using politics of fear and strong leadership nurtured by institutional context having weak democracy and vague separation of powers, when constitution expressly established that these functions have to be strong to address critical problem of abuse in democracy by our own rulers, our own political authorities who, if uncontrolled or made not accountable, can do great harm to society higher than (pandemic) crisis. To conclude, different factors between countries that are not only parameters related to medicine but also to social and political sciences can explain the effects of COVID-19 pandemic in society not only in terms of health but also in term of human and civil rights that should be accurately assessed to control future negative impact of pandemic crisis on public health, economy and society. It is worth raising the question whether our constitutional ordering of Western and democratic countries is still protecting us from fear and effective tangible democratic reduction that can became a hazardous process, similar to COVID-19 pandemic crisis, that direct future society towards terra incognita of uncertain social events.

\section{REFERENCES}

Abbasi J. 2020. COVID-19 and mRNA Vaccines-First Large Test for a New Approach. JAMA, 324(12), 1125-1127. https://doi.org/10.1001/jama.2020.16866

Abuza Z. 2020. Explaining Successful (and Unsuccessful) COVID-19 Responses in Southeast Asia. The Diplomat. Retrieved July 7, 2020, from https://thediplomat.com/2020/04/explaining-successful-and-unsuccessfulcovid-19responses-in-southeast-asia/

Akamatsu, T., Nagae, T., Osawa, M., Satsukawa, K., Sakai, T., Mizutani, D. 2021. Model-based analysis on social acceptability and feasibility of a focused protection strategy against the COVID-19 pandemic. Scientific reports, 11(1), 2003. https://doi.org/10.1038/s41598-021-81630-9

Research paper 2021 Coccia M. 2021. Maximum level of COVID-19 vaccination in rich and democratic countries, National Research Council of Italy 
Aldila, D., Samiadji, B.M., Simorangkir, G.M., Khosnaw, S.H.A., Shahzad, M.2021. Impact of early detection and vaccination strategy in COVID-19 eradication program in Jakarta, Indonesia, BMC Research Notes, 14(1),132

Anderson, R. M., Vegvari, C., Truscott, J., Collyer, B. S. 2020. Challenges in creating herd immunity to SARS-CoV2 infection by mass vaccination. Lancet (London, England), 396(10263), $1614-1616$. https://doi.org/10.1016/S0140-6736(20)32318-7

Angelopoulos A. N., Pathak R., Varma R., Jordan M. I. 2020. On Identifying and Mitigating Bias in the Estimation of the COVID-19 Case Fatality Rate. Harvard Data Science Review. https://doi.org/10.1162/99608f92.f01ee285

Anttiroiko Ari-Veikko, 2021. Successful Government Responses to the Pandemic: Contextualizing National and Urban Responses to the COVID-19 Outbreak in East and West. International Journal of E-Planning Research (IJEPR), IGI Global, vol. 10(2), pages 1-17, April.

Arato, A. (2004). Introduction. Social Research, 71(4), 965-966. http://www.jstor.org/stable/40971986

Ardito L., Coccia M., Messeni Petruzzelli A. 2021. Technological exaptation and crisis management: Evidence from COVID-19 outbreaks. R\&D Management, vol. 51, n. 4, pp. 381-392. Special Issue: Providing solutions in emergencies: R\&D and innovation management during Covid-19 Part-2, September 2021, https://doi.org/10.1111/radm.12455

Aschwanden C. 2020. The false promise of herd immunity for COVID-19. Nature. Nov;587(7832):26-28. doi: 10.1038/d41586-020-02948-4

Aschwanden C. 2021. Five reasons why COVID herd immunity is probably impossible. Nature, 591(7851), 520-522. https://doi.org/10.1038/d41586-021-00728-2

Bontempi E., Coccia M., 2021. International trade as critical parameter of COVID-19 spread that outclasses demographic, economic, environmental, and pollution factors, Environmental Research, vol. 201, Article number 111514, PII S0013-9351(21)00808-2, https://doi.org/10.1016/j.envres.2021.111514.

Bontempi E., Coccia M., Vergalli S., Zanoletti A. 2021. Can commercial trade represent the main indicator of the COVID-19 diffusion due to human-to-human interactions? A comparative analysis between Italy, France, and Spain, Environmental Research, vol. 201, Article number 111529, https://doi.org/10.1016/j.envres.2021.111529

Brown, R., Kelly, D., Wilkinson, D., \& Savulescu, J. (2021). The scientific and ethical feasibility of immunity passports. The Lancet. Infectious diseases, 21(3), e58-e63. https://doi.org/10.1016/S1473-3099(20)30766-0

Buttenheim, A. M., \& Asch, D. A. (2013). Making vaccine refusal less of a free ride. Human vaccines \& immunotherapeutics, 9(12), 2674-2675. https://doi.org/10.4161/hv.26676

Calabrese G., Coccia M., Rolfo S. 2005. Strategy and market management of new product development: evidence from Italian SMEs. International Journal of Product Development, vol. 2, n. 1-2, pp. 170-189. https://doi.org/10.1504/IJPD.2005.006675

Chantler, T., Karafillakis, E., \& Wilson, J. (2019). Vaccination: Is There a Place for Penalties for Non-compliance? Applied health economics and health policy, 17(3), 265-271. https://doi.org/10.1007/s40258-019-00460-z

Coccia M. 2005. A taxonomy of public research bodies: a systemic approach, Prometheus, vol. 23, n. 1, pp. 63-82. https://doi.org/10.1080/0810902042000331322

Coccia M. 2005a. Countrymetrics: valutazione della performance economica e tecnologica dei paesi e posizionamento dell'Italia, Rivista Internazionale di Scienze Sociali, vol. CXIII, n. 3, pp. 377-412. Stable URL: http://www.jstor.org/stable/41624216. 
Coccia M. 2008. Measuring scientific performance of public research units for strategic change. Journal of Informetrics, vol. 2, n. 3, pp. 183-194. https://doi.org/10.1016/j.joi.2008.04.001

Coccia M. 2014. Steel market and global trends of leading geo-economic players. International Journal of trade and global markets, vol. 7, n.1, pp. 36-52, http://dx.doi.org/10.1504/IJTGM.2014.058714

Coccia M. 2015. Spatial relation between geo-climate zones and technological outputs to explain the evolution of technology. Int. J. Transitions and Innovation Systems, vol. 4, nos. 1-2, pp. 5-21, http://dx.doi.org/10.1504/IJTIS.2015.074642.

Coccia M. 2016. Problem-driven innovations in drug discovery: co-evolution of the patterns of radical innovation with the evolution of problems, Health Policy and Technology, vol. 5, n. 2, pp. 143-155. https://doi.org/10.1016/j.hlpt.2016.02.003

Coccia M. 2017. Varieties of capitalism's theory of innovation and a conceptual integration with leadership-oriented executives: the relation between typologies of executive, technological and socioeconomic performances. Int. J. Public Sector Performance Management, Vol. 3, No. 2, pp. 148-168. https://doi.org/10.1504/IJPSPM.2017.084672

Coccia M. 2017a. Disruptive firms and industrial change, Journal of Economic and Social Thought, vol. 4, n. 4, pp. 437-450, http://dx.doi.org/10.1453/jest.v4i4.1511

Coccia M. 2017b. New directions in measurement of economic growth, development and under development, Journal of Economics and Political Economy, vol. 4, n. 4, pp. 382-395, http://dx.doi.org/10.1453/jepe.v4i4.1533

Coccia M. 2017c. Sources of disruptive technologies for industrial change. L'industria -rivista di economia e politica industriale, vol. 38, n. 1, pp. 97-120, DOI: 10.1430/87140

Coccia M. 2017d. Sources of technological innovation: Radical and incremental innovation problem-driven to support competitive advantage of firms. Technology Analysis \& Strategic Management, vol. 29, n. 9, pp. 1048-1061, https://doi.org/10.1080/09537325.2016.1268682

Coccia M. 2018. An introduction to the methods of inquiry in social sciences, Journal of Social and Administrative Sciences, vol. 5, n. 2, pp. 116-126, http://dx.doi.org/10.1453/jsas.v5i2.1651

Coccia M. 2018a. An introduction to the theories of institutional change, Journal of Economics Library, vol. 5, n. 4, pp. 337-344, http://dx.doi.org/10.1453/jel.v5i4.1788

Coccia M. 2018b. General properties of the evolution of research fields: a scientometric study of human microbiome, evolutionary robotics and astrobiology, Scientometrics, vol. 117, n. 2, pp. 1265-1283, https://doi.org/10.1007/s11192-018-2902-8

Coccia M. 2018c. The origins of the economics of Innovation, Journal of Economic and Social Thought, vol. 5, n. 1, pp. 9-28, http://dx.doi.org/10.1453/jest.v5i1.1574

Coccia M. 2018d. The relation between terrorism and high population growth, Journal of Economics and Political Economy, vol. 5, n. 1, pp. 84-104, http://dx.doi.org/10.1453/jepe.v5i1.1575

Coccia M. 2019. Metabolism of public organizations: A case study, Journal of Social and Administrative Sciences, vol. 6, no. 1, pp. 1-9, http://dx.doi.org/10.1453/jsas.v6i1.1793

Coccia M. 2019a. The theory of technological parasitism for the measurement of the evolution of technology and technological forecasting, Technological Forecasting and Social Change, vol. 141, pp. 289-304, https://doi.org/10.1016/j.techfore.2018.12.012 
Coccia M. 2019b. A Theory of classification and evolution of technologies within a Generalized Darwinism,

Technology Analysis \& Strategic Management, vol. 31, n. 5, pp. 517-531, http://dx.doi.org/10.1080/09537325.2018.1523385

Coccia M. 2019c. Theories of Development. A. Farazmand (ed.), Global Encyclopedia of Public Administration, Public Policy, and Governance, Springer Nature, https://doi.org/10.1007/978-3-319-31816-5_939-1

Coccia M. 2019d. The Role of Superpowers in Conflict Development and Resolutions. A. Farazmand (ed.), Global Encyclopedia of Public Administration, Public Policy, and Governance, Springer Nature Switzerland AG, https://doi.org/10.1007/978-3-319-31816-5_3709-1

Coccia M. 2019e. Theories of Self-determination. A. Farazmand (ed.), Global Encyclopedia of Public Administration, Public Policy, and Governance, Springer Nature Switzerland AG, https://doi.org/10.1007/978-3-319-318165_3710-1.

Coccia M. 2019f. Why do nations produce science advances and new technology? Technology in society, vol. 59, November, 101124, pp. 1-9, https://doi.org/10.1016/j.techsoc.2019.03.007

Coccia M. 2019g. Comparative Incentive Systems. A. Farazmand (ed.), Global Encyclopedia of Public Administration, Public Policy, and Governance, Springer Nature Switzerland AG, https://doi.org/10.1007/978-3319-31816-5_3706-1

Coccia M. 2020. An index to quantify environmental risk of exposure to future epidemics of the COVID-19 and similar viral agents: Theory and Practice. Environmental Research, volume 191, December, Article number 110155. https://doi.org/10.1016/j.envres.2020.110155

Coccia M. 2020a. Factors determining the diffusion of COVID-19 and suggested strategy to prevent future accelerated viral infectivity similar to COVID. Science of The Total Environment, vol. 729, n.138474, https://doi.org/10.1016/j.scitotenv.2020.138474.

Coccia M. 2020b. How (Un)sustainable Environments are Related to the Diffusion of COVID-19: The Relation between Coronavirus Disease 2019, Air Pollution, Wind Resource and Energy. Sustainability, 12, 9709; doi:10.3390/su12229709

Coccia M. 2020c. How do environmental, demographic, and geographical factors influence the spread of COVID19. Journal of Social and Administrative Sciences, vol. 7, no. 3, pp. 169-209. http://dx.doi.org/10.1453/jsas.v7i3.2018

Coccia M. 2020d. Destructive Technologies for Industrial and Corporate Change. In: Farazmand A. (eds), Global Encyclopedia of Public Administration, Public Policy, and Governance. Springer, Cham, https://doi.org/10.1007/978-3-319-31816-5_3972-1

Coccia M. 2020e. Deep learning technology for improving cancer care in society: New directions in cancer imaging driven by artificial intelligence. Technology in Society, vol. 60, pp. 1-11, art. n. 101198, https://doi.org/10.1016/j.techsoc.2019.101198

Coccia M. 2020f. How does science advance? Theories of the evolution of science. Journal of Economic and Social Thought, vol. 7, n. 3, pp. 153-180. http://dx.doi.org/10.1453/jest.v7i3.2111

Coccia M. 2020g. The evolution of scientific disciplines in applied sciences: dynamics and empirical properties of experimental physics, Scientometrics, n. 124, pp. 451-487. https://doi.org/10.1007/s11192-020-03464-y

Coccia M. 2021. Effects of the spread of COVID-19 on public health of polluted cities: results of the first wave for explaining the dejà vu in the second wave of COVID-19 pandemic and epidemics of future vital agents. 
Environmental Science and Pollution Research. 28(15), 19147-19154. https://doi.org/10.1007/s11356-020-116627

Coccia M. 2021a. Optimal levels of vaccination to reduce COVID-19 infected individuals and deaths: A global analysis. Environmental Research, Article number 112314, https://doi.org/10.1016/j.envres.2021.112314

Coccia M. 2021b. Pandemic Prevention: Lessons from COVID-19. Encyclopedia 2021, 1, 433-444. MDPI, Basel, Switzerland, Encyclopedia of COVID-19, open access journal, https://doi.org/10.3390/encyclopedia1020036

Coccia M. 2021c. Comparative Critical Decisions in Management. In: Farazmand A. (eds), Global Encyclopedia of Public Administration, Public Policy, and Governance. Springer Nature Switzerland AG 2020, Springer, Cham. https://doi.org/10.1007/978-3-319-31816-5_3969-1

Coccia M. 2021d. The impact of first and second wave of the COVID-19 pandemic: comparative analysis to support control measures to cope with negative effects of future infectious diseases in society. Environmental Research, vol. 197, June, Article number 111099, PII S0013-9351(21)00393-5, https://doi.org/10.1016/j.envres.2021.111099

Coccia M. 2021e. High health expenditures and low exposure of population to air pollution as critical factors that can reduce fatality rate in COVID-19 pandemic crisis: a global analysis Environmental Research, vol. 199, Article number 111339, https://doi.org/10.1016/j.envres.2021.111339

Coccia M. 2021f. How do low wind speeds and high levels of air pollution support the spread of COVID-19? Atmospheric Pollution Research, vol. 12, n.1, pp. 437-445., https://doi.org/10.1016/j.apr.2020.10.002.

Coccia M. 2021g. The relation between length of lockdown, numbers of infected people and deaths of COVID-19, and economic growth of countries: Lessons learned to cope with future pandemics similar to Covid-19. Science of The Total Environment, n. 145801. https://doi.org/10.1016/j.scitotenv.2021.145801

Coccia M. 2021h. The effects of atmospheric stability with low wind speed and of air pollution on the accelerated transmission dynamics of COVID-19. International Journal of Environmental Studies, vol. 78, n. 1, pp. 1-27, https://doi.org/10.1080/00207233.2020.1802937

Coccia M. 2021i. How a Good Governance of Institutions Can Reduce Poverty and Inequality in Society? In Nezameddin Faghih, Ali Hussein Samadi (Editor) Legal-Economic Institutions, Entrepreneurship, and Management, Perspectives on the Dynamics of Institutional Change from Emerging Markets, Springer Nature DOI 978-3-030-60978-8_4, (eBook) https://doi.org/10.1007/978-3-030-60978-8, pp. 65-94

Coccia M. 2022. Preparedness of countries to face covid-19 pandemic crisis: Strategic positioning and underlying structural factors to support strategies of prevention of pandemic threats, Environmental Research, Volume 203, n. 111678, https://doi.org/10.1016/j.envres.2021.111678.

Coccia M., Bellitto M. 2018. Human progress and its socioeconomic effects in society, Journal of Economic and Social Thought, vol. 5, n. 2, pp. 160-178, http://dx.doi.org/10.1453/jest.v5i2.1649

Coccia M., Benati I. 2018. Rewards in public administration: A proposed classification, Journal of Social and Administrative Sciences, vol. 5, n. 2, pp. 68-80, http://dx.doi.org/10.1453/jsas.v5i2.1648.

Coccia M., Cadario E. 2014. Organisational (un)learning of public research labs in turbulent context. International Journal of Innovation and Learning, vol. 15, n. 2, pp.115-129, https://doi.org/10.1504/IJIL.2014.059756

Coccia M., Finardi U. 2012. Emerging nanotechnological research for future pathway of biomedicine. International Journal of Biomedical nanoscience and nanotechnology, vol. 2, nos. 3-4, pp. $299-317$. DOI: 10.1504/IJBNN.2012.051223

Research paper 2021 Coccia M. 2021. Maximum level of COVID-19 vaccination in rich and democratic countries, National Research Council of Italy 
Coccia M., Finardi U. 2013. New technological trajectories of non-thermal plasma technology in medicine. Int. J. Biomedical Engineering and Technology, vol. 11, n. 4, pp. 337-356, DOI: 10.1504/IJBET.2013.055665

Coccia M., Rolfo S. 2000. Ricerca pubblica e trasferimento tecnologico: il caso della regione Piemonte in Rolfo S. (eds) Innovazione e piccole imprese in Piemonte, Franco Angeli Editore, Milano (Italy), ISBN: 9788846418784

Coccia M., Rolfo S. 2008. Strategic change of public research units in their scientific activity, Technovation, vol. 28, n. 8, pp. 485-494. https://doi.org/10.1016/j.technovation.2008.02.005

Coccia M., Watts J. 2020. A theory of the evolution of technology: technological parasitism and the implications for innovation management, Journal of Engineering and Technology Management, vol. 55 (2020) 101552, S09234748(18)30421-1,https://doi.org/10.1016/j.jengtecman.2019.11.003

Crowther, William. 2017. "Ethnic Condominium and Illiberalism in Macedonia." East European Politics and Societies 31 (4):739-61. doi:10.1177/0888325417716515.

Dashtbali M., Mirzaie M. 2021. A compartmental model that predicts the effect of social distancing and vaccination on controlling COVID-19, Scientific Reports, 11(1),8191

de Vlas, S. J., Coffeng, L. E. 2021. Achieving herd immunity against COVID-19 at the country level by the exit strategy of a phased lift of control. Scientific reports, 11(1), 4445. https://doi.org/10.1038/s41598-021-83492-7

Debiec, J., \& LeDoux, J. (2004). Fear and the Brain. Social Research, 71(4), 807-818. http://www.jstor.org/stable/40971979

Dye, C., \& Mills, M. C. (2021). COVID-19 vaccination passports. Science (New York, N.Y.), 371(6535), 1184. https://doi.org/10.1126/science.abi5245

Echoru, I., Ajambo, P.D., Keirania, E., Bukenya, E.E.M.2021. Sociodemographic factors associated with acceptance of COVID-19 vaccine and clinical trials in Uganda: a cross-sectional study in western Uganda, BMC Public Health 21(1),1106

Fontanet A., Cauchemez, S. 2020. COVID-19 herd immunity: where are we? Nature reviews. Immunology, 20(10), 583-584. https://doi.org/10.1038/s41577-020-00451-5

Freedom House (2021). Countries and Territories. https://freedomhouse.org/countries/freedom-world/scores (Accessed November 2021)

Freedom House (2021a). Freedom in the World 2020 Methodology. https://freedomhouse.org/reports/freedomworld/freedom-world-research-methodology (Accessed 5 November 2021)

Gore, A. (2004). The Politics of Fear. Social Research, 71(4), 779-798. http://www.jstor.org/stable/40971977

Günay, Cengiz, and Vedran Dzihic. 2016. “Decoding the Authoritarian Code: Exercising 'Legitimate' Power Politics through the Ruling Parties in Turkey, Macedonia and Serbia.” Southeast European and Black Sea Studies 16 (4):529_ 49. doi:10.1080/14683857.2016.1242872.

Johns Hopkins Center for System Science and Engineering, 2021. Coronavirus COVID-19 Global Cases, https://gisanddata.maps.arcgis.com/apps/opsdashboard/index.html\#/bda7594740fd40299423467b48e9ecf6 (accessed in 4 November 2021).

Kamin-Friedman, S., \& Peled Raz, M. (2021). Lessons from Israel's COVID-19 Green Pass program. Israel journal of health policy research, 10(1), 61. https://doi.org/10.1186/s13584-021-00496-4

Kanyike A. M., Olum R., Kajjimu J., Ojilong D., Akech G. M., Nassozi D. R., Agira D., Wamala N. K., Asiimwe A., Matovu D., Nakimul, A. B., Lyavala M., Kulwenza P., Kiwumulo J., Bongomin, F. 2021. Acceptance of the 
coronavirus disease-2019 vaccine among medical students in Uganda. Tropical medicine and health, $49(1), 37$. https://doi.org/10.1186/s41182-021-00331-1

Kosciejew, M.R.H. (2021), "COVID-19 immunity (or vaccine) passports: a documentary overview and analysis of regimes of health verification within the coronavirus pandemic", Journal of Documentation, Vol. ahead-of-print No. ahead-of-print. https://doi.org/10.1108/JD-04-2021-0079

Kwok K. O., Lai F., Wei W. I., Wong S., Tang J. 2020. Herd immunity - estimating the level required to halt the COVID-19 epidemics in affected countries. The Journal of infection, 80(6), e32-e33. https://doi.org/10.1016/j.jinf.2020.03.027

Lupia, A., \& Menning, J. O. (2009). When Can Politicians Scare Citizens into Supporting Bad Policies? American Journal of Political Science, 53(1), 90-106. http://www.jstor.org/stable/25193869

Luster, T., Albin, E., Gross, A., Tabenkin, M., \& Davidovitch, N. (2021). Promoting Vaccination from a Human Rights and Equity Perspective: Lessons from the Israeli “Green Pass". European Journal of Risk Regulation, 12(2), 308-320. doi:10.1017/err.2021.36

MAYO CLINIC 2021. Different types of COVID-19 vaccines: How they work. https://www.mayoclinic.org/diseases-conditions/coronavirus/in-depth/different-types-of-covid-19-vaccines/art20506465 (accessed 6 September 2021).

Miran Lavrič \& Florian Bieber (2021) Shifts in Support for Authoritarianism and Democracy in the Western Balkans, Problems of Post-Communism, 68:1, 17-26, DOI: 10.1080/10758216.2020.1757468

Murphy J., Vallières F., Bentall R.P., (...), Karatzias T., Hyland P. 2021. Psychological characteristics associated with COVID-19 vaccine hesitancy and resistance in Ireland and the United Kingdom, Nature Communications, $12(1), 29$

Norris P. 2008. Driving Democracy. Do Power-Sharing Institutions Work? Publisher: Cambridge University Press. Online publication date: September 2012. Online ISBN: $9780511790614 . \quad$ DOI: https://doi.org/10.1017/CBO9780511790614

Our World in Data 2021. Coronavirus (COVID-19) Vaccinations - Statistics and Research - Our World in Data https://ourworldindata.org/covid-vaccinations (Accessed 19 October 2021)

Pagliaro M., Coccia M. 2021. How self-determination of scholars outclasses shrinking public research lab budgets, supporting scientific production: a case study and R\&D management implications. Heliyon. vol. 7, n. 1, e05998. https://doi.org/10.1016/j.heliyon.2021.e05998

Phelan A. L. (2020). COVID-19 immunity passports and vaccination certificates: scientific, equitable, and legal challenges. Lancet (London, England), 395(10237), 1595-1598. https://doi.org/10.1016/S0140-6736(20)31034-5

Prewitt, K., Alterman, E., Arato, A., Pyszczynski, T., Robin, C., \& Stern, J. (2004). The Politics of Fear after 9/11. Social Research, 71(4), 1129-1146. http://www.jstor.org/stable/40971995

Prieto Curiel, R., González Ramírez, H. 2021. Vaccination strategies against COVID-19 and the diffusion of antivaccination views, Scientific Reports 11(1),6626

Randolph H. E., Barreiro L. B. 2020. Herd immunity: understanding COVID-19. Immunity 52, 737-741

Redwan E. M. 2021. COVID-19 pandemic and vaccination build herd immunity. European review for medical and pharmacological sciences, 25(2), 577-579. https://doi.org/10.26355/eurrev_202101_24613

$\underline{\text { Research paper }}$

2021

Coccia M. 2021. Maximum level of COVID-19 vaccination in rich and democratic countries, National Research Council of Italy 
Ritchie H., Ortiz-Ospina E., Beltekian D., Mathieu E., Hasel J., Macdonald B., Giattino C., Roser, M. 2020. Policy Responses to the Coronavirus Pandemic. Our World in Data, Statistics and Research. Retrieved July 7, 2020, from https://ourworldindata.org/policy-responses-covid

Robin, C. (2004). Liberalism at Bay, Conservatism at Play: Fear in the Contemporary Imagination. Social Research, 71(4), 927-962. http://www.jstor.org/stable/40971985

Saban, M., Myers, V., Ben Shetrit, S., \& Wilf-Miron, R. (2021). Issues surrounding incentives and penalties for COVID-19 vaccination: The Israeli experience. Preventive medicine, 153, 106763. Advance online publication. https://doi.org/10.1016/j.ypmed.2021.106763

Schwarzinger M, Watson V, Arwidson P, Alla F, Luchini S. 2021. COVID-19 vaccine hesitancy in a representative working-age population in France: a survey experiment based on vaccine characteristics. Lancet Public Health 2021; published online Feb 5. https://doi.org/10.1016/S2468-2667(21)00012-8.

Soveri, A., Karlsson, L.C., Antfolk, J., Lindfelt, M., Lewandowsky, S. 2021 Unwillingness to engage in behaviors that protect against COVID-19: the role of conspiracy beliefs, trust, and endorsement of complementary and alternative medicine, BMC Public Health, 21(1),684

The World Bank (2021). GDP per capita (constant 2015 US\$), World Bank national accounts data, and OECD National Accounts data files. https://data.worldbank.org/indicator/NY.GDP.PCAP.KD (Accessed November 2021)

Vergara, R., Sarmiento, P., \& Lagman, J. (2021). Building public trust: a response to COVID-19 vaccine hesitancy predicament. Journal of public health (Oxford, England), 43(2), e291-e292. https://doi.org/10.1093/pubmed/fdaa282

Verger, P., Peretti-Watel, P. (2021). Understanding the determinants of acceptance of COVID-19 vaccines: a challenge in a fast-moving situation. The Lancet. Public health, 6(4), e195-e196. https://doi.org/10.1016/S24682667(21)00029-3

Vinceti, M., Filippini, T., Rothman, K. J., Di Federico, S., \& Orsini, N. 2021. SARS-CoV-2 infection incidence during the first and second COVID-19 waves in Italy. Environmental research, 197, 111097. https://doi.org/10.1016/j.envres.2021.111097

Vladisavljević, Nebojša. 2019. "Media Discourse and the Quality of Democracy in Serbia after Milošević." EuropeAsia Studies. doi:10.1080/09668136.2019.1669534

Waitzberg, Ruth, Noa Triki, Sharon Alroy-Preis, Tomer Lotan, Liat Shiran, and Nachman Ash. 2021. "The Israeli Experience with the "Green Pass" Policy Highlights Issues to Be Considered by Policymakers in Other Countries" International Journal of Environmental Research and Public Health 18, no. 21: 11212. https://doi.org/10.3390/ijerph182111212

Wesołowski, W. (1990). Transition from Authoritarianism to Democracy. Social Research, 57(2), $435-461$. http://www.jstor.org/stable/40970595

Wilf-Miron, R., Myers, V., Saban, M. (2021). Incentivizing Vaccination Uptake: The "Green Pass" Proposal in Israel. JAMA, 325(15), 1503-1504. https://doi.org/10.1001/jama.2021.4300

Wong, L. 1991. Authoritarianism and Transition to Democracy in a Third World State', Critical Sociology, 18(2), pp. 77-101. doi: 10.1177/089692059101800204. 